\title{
KSIAŻKI O FILMIE
}

\section{Polska sztuka mediów w rozszerzonym polu}

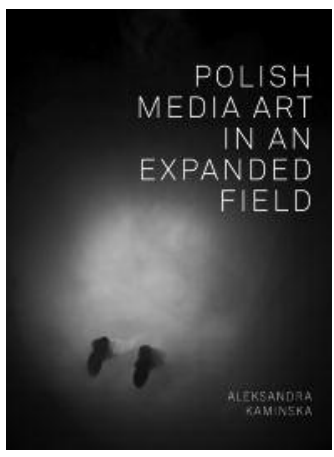

\author{
RYSZARD W. KLUSZCZYŃSKI
}

Książka Aleksandry Kaminskiej Polish Media Art in an Expanded Field jest najnowszą (i ciągle jedyną wydaną poza granicami Polski w takim formacie) publikacją w całości poświęconą współczesnej sztuce medialnej w Polsce. Przyjmując perspektywę oglądu polskiej sztuki mediów w rozszerzonym polu Aleksandra Kaminska dokonuje jedynego właściwego wyboru. Sztuka mediów w czasach postmedialnych ulega rozproszeniu, przestaje być osobnym fenomenem. Procesy konwergencji i remediacji technologicznej, w powiązaniu z dominującą transmedialną strategią artystyczną sprawiły, że media stają się instrumentami różnorakich wypowiedzi artystycznych, nie kreują odrębnej dziedziny artystycznej ani też nie nadają artystom ich używającym odrębnego statusu artysty medialnego. Kaminska zajmuje się twórczością artystów wykorzystujących media w swojej pracy, zwracając przy tym uwagę na problematykę tworzonych dzieł. Wyraża przekonanie, że twórczość artystyczna jest lokalnym wytworem, products of site-specific ecologies and histories (s. 15) i chce ją badać jako taką właśnie. Określa przy tym bardzo wąskie ramy czasowe swego obszaru badań: lata 2004-2009, pierwsze pięciolecie przynależności Polski do UE. Uznaje, że sztuka w tej sytuacji porzuca autonomię, jest zanurzona w politykę, a artyści są zaangażowani w negocjacje podstawowych wartości społecznych. Odnajduje wśród nich przede wszystkim problematykę tożsamości, rozważania nad porządkiem społecznym i specyfiką miejsca (postsocjalizm, demokracja, europejskość). Zwraca uwagę na istotną rolę eksperymentu jako metody pracy artystycznej. Dostrzega znaczenie postaw krytycznych. Pyta także o to, jak artystyczne historie, praktyki i warunki są wpisywane w praktykę sztuki mediów. To ostatnie sprawia, że autorka osadza wybrany do analizy okres w rozważaniach o charakterze historycznym sięgających historycznych awangard, choć przede wszystkim skupionych na latach bezpośrednio poprzedzających badany okres. To on i sztuka wówczas tworzona stanowią podstawowy przedmiot badań.

W swych wyborach artystycznych dotyczących badanego okresu autorka przyjmuje optykę nie-polskiego czytelnika. To do niego adresuje książkę, dzięki czemu 
konieczne jest wpisanie jej w dyskursy dominujące w zachodniej refleksji nad sztuką. Obok dzieł artystów i artystek obecnych w międzynarodowym obiegu przedstawia prace twórców mniej nieznanych poza Polską bądź zupełnie nieznanych. Również jej własna perspektywa, badaczki spoza analizowanego obszaru, choć znającej język polski, skutkuje świeżością ujęcia, wpisaniem badanych zjawisk $\mathrm{w}$ nieczęsto wykorzystywane $\mathrm{w}$ związku $\mathrm{z}$ nimi konteksty pojęciowe. Wszystko to sprawia, że książka Aleksandry Kaminskiej jest pozycją bardzo oryginalną, wartościową, cenną dla wszystkich grup czytelniczych, także tych, dla których jej zdaniem nie jest przeznaczona, na przykład polskich odbiorców.

Recenzja książki nie może być propozycją odmiennego spojrzenia na analizowane w niej zjawiska. Sztukę można badać na wiele sposobów, a ten proponowany przez Kaminską jest wystarczająco interesujący, żeby z nim nie polemizować, proponując inne możliwe podejścia. Krytyczne uwagi wynikają z refleksji nad niektórymi przyjmowanymi przez autorkę założeniami oraz ich konsekwencjami. Nie wszystkie bowiem, jak sądzę, adekwatnie oddają obraz polskiej sztuki mediów.

Uwaga pierwsza - wybór okresu. Autorka zakłada, że szczególne okoliczności społeczno-polityczne zmusiły artystów i artystki do zmierzenia się z wyzwaniami płynącymi z akcesu Polski do Unii Europejskiej. Tymczasem wielu i wiele z nich reagowało wówczas na zupełnie inne problemy, a ich sztuka nie mieściła się w wybranym paradygmacie. Wybór ten wydaje się więc nieco sztuczny. Wiele ważnych zjawisk artystycznych rozpoczęło się w latach 90 . ubiegłego stulecia, wiele też uzyskało dojrzały kształt dopiero w bieżącej dekadzie. Autorka co prawda elastycznie podchodzi do przyjętych założeń i wykracza w swych badaniach poza wybrane pięciolecie, jednak jej teza, że w latach 2004-2009 zdarzyło się w polskiej sztuce mediów coś nadzwyczajnego, jest nieuzasadniona. Dzieła powstałe w tym okresie nie stanowią najlepszej czy też wyjątkowej reprezentacji współczesnej sztuki mediów w Polsce.

Uwaga druga - wybór artystów. Decyzja o nadaniu istotnego znaczenia latom 2004-2009 i pojawiającej się w nich problematyce nieuchronnie wpłynęła na wybór artystów i dzieł egzemplifikujących rozważane w książce zagadnienia. Nie zamierzam go podważać, dzięki niemu możemy spojrzeć na sztukę mediów w Polsce pierwszej dekady XXI w. inaczej niż w przypadku dotychczasowych opracowań. Ubolewam jednak, że Kaminska nie dostrzegła znaczenia prac Anny Baumgart i Anny Konik. Każda z nich zrealizowała w wybranym przez autorkę okresie kilka bardzo ważnych prac, co więcej - ich twórczość została zainicjowana w latach okres ten poprzedzających i była kontynuowana w kolejnej dekadzie. W analizowanym przez Kamińską czasie Anna Baumgart zrealizowała m.in. Ekstatyczki, histeryczki i inne święte (w roku 2004), transmedialne projekty Weronika AP i Natascha Kampusch (2006), Hipoteze skradzionego obrazu i Do utworu o matce i ojczyźnie Bożeny Kneff (2008). Anna Konik natomiast: In the Middle of the Way (2001-2007); Przezroczystość (2004), Our Lady's Forever (2006), Wille zauroczonych (2009). Sztuka Baumgart jest skupiona w znacznym stopniu na sytuacji kobiet w społeczeństwach patriarchalnych, sztuka Konik natomiast na społecznościach marginalizowanych, wykluczanych, prześladowanych. Spektrum zainteresowania artystek nie jest specyficznie polskie, Konik niektóre ze swych prac realizowała poza Polską. Jednak znaczenie ich dzieł, także dla polskiej sztuki, jest niepodważalne, więc powinny one zostać uwzględnione, biorąc pod uwagę strategię przyjętą przez Kamin- 
ską. Uznanie roku 2009 za cezurę sprawiło z kolei, że nie została uwzględniona twórczość grupy panGenerator, która rozpoczęła działalność w roku 2011, a w kolejnych latach przedstawiła wiele ważnych prac lokujących się w przestrzeni interakcji sztuki i technologii cyfrowych oraz sztuki i designu, inicjując ważny nurt we współczesnej sztuce mediów w Polsce.

Uwaga trzecia - dzieła wymienionych powyżej artystów wpływają na kwestię rozumienia autonomii sztuki, która nie jest przez nich pomijana, a niekiedy przyjmuje szczególną postać. Baumgart i Konik budują perspektywę transnarodową. Ich usytuowana między „tu i gdzie indziej” twórczość zyskuje autonomię bliską dążeniom uniwersalistycznym, choć nietożsamą z nimi. Z kolei konflikt z niezależnością sztuki charakterystyczny dla transrodzajowej i transmedialnej twórczości panGeneratora odbywa się na zupełnie innym polu niż w przypadku artystów analizowanych przez Kaminską. A ponieważ podobnych przykładów w rozważanym okresie jest więcej, każe to krytycznie odnieść się do stanowiska przypisującego polskiej sztuce mediów porzucenie autonomii na rzecz zainteresowań społeczno-politycznych.

Uwaga czwarta - kwestionowana przez Kaminską obecność polskiej sztuki w świecie przed 1989 r. Sztuka mediów nie zawsze funkcjonowała w rozproszeniu. W latach 70. alternatywni artyści filmowi i wideo, w Polsce zrzeszeni w grupie Warsztat Formy Filmowej, tworzyli osobną formację. I o ile się można zgodzić z tym, że przed rokiem 1990 twórczość polskich malarzy czy rzeźbiarzy była w bardzo niewielkim stopniu (jeśli w ogóle) obecna w światowym obiegu sztuki, to nie da się tego powiedzieć o awangardowych filmowcach, których dzieła były regularnie pokazywane na najważniejszych światowych imprezach, od Knokke-Heist Festival (lata 1974-1975), przez Documenta (1977), po Film as Film (1979). Były także dystrybuowane przez organizacje takie, jak np. London Filmmakers' Co-op. To dopiero dekada, którą zapoczątkował stan wojenny spowodowała, że polscy artyści medialni wypadli na dziesięć lat z obiegu międzynarodowego, a potem byli na nowo odkrywani przez młodsze pokolenia. Przywołani przez autorkę lokalni badacze głoszący nieobecność polskich artystów w zachodnich kręgach nie zajmowali się sztuką mediów i nie śledzili jej losów w światowym obiegu, a ich opinie dotyczyły w zasadzie sztuki nowoczesnego mainstreamu.

Uwaga piąta - Polska jako kraj wschodnio- bądź środkowoeuropejski. Uogólnienia, jak te wskazane powyżej, w lokalnej refleksji zdarzają się często. Kaminska, skazana na korzystanie z niej, powiela niekiedy charakterystyczne dla niej ułomności. Należy do nich przekonanie o szczególnie poważnych konsekwencjach, że sztuka krajów Europy Wschodniej i Środkowej to koherentny zbiór zjawisk, a sądy formułowane w odniesieniu do jednego z nich można równie dobrze zastosować wobec innych. Tymczasem całościowa perspektywa, zapewne użyteczna dla badań społecznych i politologicznych, jest zdecydowanie za szeroka w odniesieniu do sztuki. Pomija specyficzne właściwości decydujące o obliczu dzieł powstających w określonych miejscach. Geopolityczna wspólnota losu i wspólne wkroczenie w struktury polityczne Unii Europejskiej nie zlikwidowały odmienności historycznych, różnorodności zaplecza artystycznego twórców pochodzących z różnych krajów. Już sama odmienność lokalnych tradycji awangardowych sprawiła, że przed 1989 r. sztuka w Polsce niezbyt przypominała sztukę w Bułgarii czy Rumunii, a sztuka węgierska bardzo różniła się od tej tworzonej w NRD bądź Albanii. Poja- 
wiające się w książce liczne sądy, które odnoszą się do sztuki wschodnio- i środkowoeuropejskiej en globe są w tej sytuacji mało wiarygodne, zarówno w szerokim ujęciu, jak i w odniesieniu do poszczególnych krajów, na przykład Polski.

Kaminska napisała książkę z perspektywy zewnętrznej wobec badanego zjawiska. Jest to korzystne o tyle, o ile prowadzi do odświeżenia jego obrazu i weryfikacji powielanych bezrefleksyjnie sądów, także (bądź szczególnie) w Polsce. Książka jest więc najciekawsza tam, gdzie autorka odnosi się do wybranych przez siebie dzieł, przeprowadza własne analizy i wyciąga wnioski. Natomiast tam, gdzie sięga po opinie innych badaczy, w opisie pojawiają się niedostatki wynikające z braku jej własnych badań źródłowych. Niektóre z jej sądów ukształtowane zostały przez publikacje, do których dotarła i badaczy, których uznała za autorytety. Obraz całościowy cierpi szczególnie wtedy, gdy okazuje się, że między wybranymi źródłami i opiniami uznanych autorytetów jest zbyt mało konfliktów i odmienności. Choć należy odnotować, że autorka wskazuje niekiedy stanowiska alternatywne wobec obowiązujących powszechnie.

Powyższe uwagi nie podważają sformułowanej wcześniej opinii, że książka Aleksandry Kaminskiej jest jedną z najciekawszych wypowiedzi na temat współczesnej sztuki w Polsce, proponując inne niż dotychczasowe jej ujęcie oraz pokazując, w ramach przyjętego przez autorkę paradygmatu, sposób, w jaki polscy artyści negocjują własną tożsamość i jak się odnoszą do nowych wyzwań społecznych.

RYSZARD W. KLUSZCZYŃSKI

Aleksandra Kaminska, Polish Media Art in an Expanded Field, Intellect Books, Chicago 2016. 